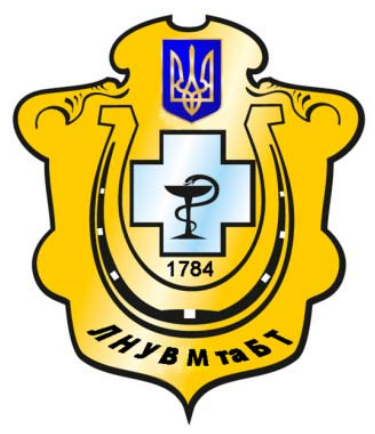

Науковий вісник Львівського національного університету ветеринарної медицини та біотехнологій імені С.3. Гжицького

Scientific Messenger of Lviv National University of Veterinary Medicine and Biotechnologies named after S.Z. Gzhytskyj

doi:10.15421/nvlvet7519

ISSN 2519-268X print

ISSN 2518-1327 online

$\underline{\text { http://nvlvet.com.ua/ }}$

УдК 637.5

\title{
Особливості використання білково-жирової емульсії в технології реструктурованих шинок
}

\author{
I.I. Кишенько ${ }^{1}$, Ю.П. Крижова ${ }^{2}$, В.О. Жук ${ }^{1}$ \\ yuliya.kryzhova@mail.ru \\ ${ }^{1}$ Національний університет харчових технологій, \\ вул. Володимирська, 68, м. Київ, 01601, Украӥна; \\ ${ }^{2}$ Національний університет біоресурсів та природокористування Украӥни, \\ вул. Генерала Родимцева, 19, м. Київ, 03041, Україна
}

\begin{abstract}
Білково-жирові емульсії, щзо забезпечують стабільну якість і високий вихід м'ясних продуктів завдяки підвищеним функціонально-технологічним властивостям, знайшли широке застосування у виробнищтві практично всіх груп м'ясних продуктів, при иьому рівень заміни м'ясної сировини може досягати 48\%. Білково-жирові емульсії дозволяють не тільки економити м'ясну сировину, а й раціонально використовувати додаткові джерела білка, жировмісної сировини в складі фаршевих систем у стабілізованому вигляді. Вивчення вітчизняної та зарубіжної літератури показало, ще нині існують різні рецептури і способи приготування білково-жирових емульсій (БЖЕ), проте їх застосування обмежене через складну технологію приготування і введення в сировину. I. Zауаs та ін. провели порівняльні дослідження властивостей фаршу і готових продуктів при використанні жиру у формі попередньо приготовлених емульсій або у вільному вигляді. Всі характеристики м'ясних фаршевих систем, що містили попередньо приготовлені емульсії, були вищими як за використання остиглого, так $i$ охолодженого м'яса. Частина наукових робіт присвячена застосуванням у складі емульсій поряд з традиційними нетрадииійних жирових і рослинних компонентів та їх використанню в продуктах харчування.

Метою роботи було удосконалення технології реструктурованих шинкових виробів в оболонці з індичого м'яса та м'яса свинини шляхом використання БЖЕ з метою збагачення їх амінокислотного та жирнокислотного складу. Використання стандартних методів дослідження та математичних розрахунків дало можливість збалансувати та обтрунтувати амінокислотний склад білкової складової иинки, оптимізувати співвідношення жирних кислот у складі жирової складової.

Критерії оптимальності, поставлені в задачі, повністю виконані, оскільки співвідношення індччого та свинячого жирів здатне задовольнити добову потребу в кислотах за кількістю $\omega-6$ та частково за кількістю $\omega-3$, а співвідношення білок:жир:волога в розробленій рецептурі БЖЕ відповідає рекомендованому діапазону 1:(3-5, 7: (3:5,7).

Ключові слова: білково-жирова емульсія, технологія, реструктуровані шинки, жирні кислоти, амінокислоти, співвідношення, м'ясо.
\end{abstract}

\section{Особенности использования белково-жировых эмульсий в технологии реструктурированных ветчин}

\author{
И.И. Кишенько ${ }^{1}$ Ю.П. Крыжова ${ }^{2}$ В.А. Жук ${ }^{1}$ \\ yuliya.kryzhova@mail.ru \\ ${ }^{1}$ Национальньй университет пищевых технологий, \\ ул. Владимирская, 68, г. Киев, 01601, Украина; \\ ${ }^{2}$ Национальний университет биоресурсов и природоиспользования Украинь, \\ ул. Генерала Родимиева, 19, г. Киев, 03041, Украина
}

Citation:

Kyshenko, I.I., Kryzhova, Y.P., Zhuk, V.O. (2017). Features of using protein-fat emulsion in technologically restructured ham. Scientific Messenger LNUVMBT named after S.Z. Gzhytskyj, 19(75), 97-101. 
Белково-жировые эмульсии, которые обеспечивают стабильное качество и высокий выход мясных продуктов благодаря высоким функциональным свойствам, нашли иирокое применение в производстве практически всех групп мясопродуктов, уровень замены мясного сырья может достигать 48\%. Белково-жировые эмульсии позволяют не только экономить мясное сырье, но и рационально использовать дополнительные источники белка, жиросодержашего сырья в составе фаршевых систем в стабилизированном виде. Изучение отечественной и зарубежной литературы показало, что сейчас существуют разные рецептуры и способы приготовления белково-жировых эмульсий (БЖЭ), однако их использование ограничено из-за сложной технологии приготовления и введения в сырье. И. Zауаs и др. провели сравнительные исследования свойств фариа и готовых продуктов при использовании жира в форме предварительно приготовленных эмульсий или в свободном виде. Все характеристики мясных фаршевых систем, которые содержали предварительно приготовленные эмульсии, были выше как при использовании остывшего, так и охлажденного мяса. Часть научных работ посвящена использованию в составе эмульсий наряду с традиционными нетрадиционных жировых и растительных компонентов и их использованию в продуктах питания.

Целью работы было усовершенствование технологии реструктурированных ветчинных изделий в оболочке из индюшиного мяса и мяса свинины путем использования БЖЭ с иелью обогашения их аминокислотного и жирнокислотного состава. Использование стандартных методов исследования и математических расчетов дало возможность сбалансировать и обосновать аминокислотный состав белковой составляющей ветчины, оптимизировать соотношение жирных кислот в составе жировой составляющей. Критерии оптимальности, поставленные в задаче, полностью выполнень, потому что соотношение индюшиного и свиного жиров будет удовлетворять суточную потребность в кислотах по количеству ш-6 и частично $\omega-3$, а соотночение белок:жир:влага в разработанной рецептуре БЖЭ отвечает рекомендованному диапазону $1:(3-5,7:(3: 5,7)$.

Ключевые слова: белково-жировая эмульсия, технология, реструктурированные ветчины, жирные кислоты, аминокислоты, соотношение, мясо.

\title{
Features of using protein-fat emulsion in technologically restructured ham
}

\author{
I.I. Kyshenko ${ }^{1}$, Y.P. Kryzhova ${ }^{2}$, V.O. Zhuk ${ }^{1}$ \\ yuliya.kryzhova@mail.ru \\ ${ }^{l}$ National University of Food Technologies, \\ Volodymyrska Str., 68, Kyiv, 01601, Ukraine; \\ ${ }^{2}$ National University of Life and Environmental Sciences of Ukraine, \\ General Rodimtsev Str., 19, Kyiv, 03041, Ukraine
}

Protein-fat emulsions that ensure consistent quality and high yield meat products due to increased functionality and technological properties, are widely used in the production of virtually all groups of meat products, while the level of raw meat substitution may reach 48\%. Protein-fat emulsion can not only save raw meat, but also rationally use additional sources of protein, fatcontaining materials consisting of ground meatsystems in stabilized form. The study of domestic and foreign literature showed that at present there are different recipes and methods of cooking protein and fat emulsions, but their use is limited because of the complex technology of preparing and commissioning raw materials. I. Zayas and others conducted a comparative study of the properties of ground meat and prepared foods using fat in the form of pre-prepared emulsions or in free form. All specifications of ground meat containing previously prepared emulsions were higher than the use of cooled and chilled meat. Some scientific papers devoted to the use of emulsion composed along with traditional and non-traditional fat and vegetable components and their use in food products.

The study of domestic and foreign literature showed that at present there are different recipes and methods of cooking protein-fat emulsions (PFE), but their use is limited because of the complex technology of preparing and incorporating into ground meat systems. The aim of that work was to improve technologically restructured ham products in the shell with turkey meat and pork by using PFE to enrich their amino acid and fatty acid composition. The use of standard methods of investigation and mathematical calculations made it possible to balance and justify the amino acid composition of the protein components of ham, to optimize the ratio fatty acids in the fat composition components. Optimal criteria, set bythe fully completed task, as a ratio of turkey and pork fat can satisfy the daily requirements in acids by the number of $\omega-6$ and partly by the number of $\omega-3$, and the ratio of protein, fat, and moisture in the developed PFE recipe meets the recommended range 1: (3-5,7: (3: 5,7).

Key words: protein-lipid emulsion, technology, restructured ham, fatty acids, amino acids, correlation, meat.

\section{Вступ}

Раціональне використання харчового потенціалу м'ясної сировини, ефективність процесів іiі перероблення є визначальними факторами у вирішенні питання, пов'язаного з задоволенням фізіологічних потреб людини, а також 3 екологічними аспектами іiі існування (Clark et al., 1994; Artemova and Ivannikova, 2002; Zonin, 2005; Salavatulina, 2005).

Проте на підприємствах м'ясопереробної промисловості весь час виникає проблема перероблення м'ясної сировини низької якості, яка пов'язана з використанням на виробництві м'яса після тривалого збері- гання, різних класифікаційних груп і сировини 3 підвищеним вмістом жиру та сполучної тканини. Тому для отримання м'ясних продуктів стабільної якості при переробленні сировини з низькими функціонально-технологічними властивостями сучасна технологія як наука передбачає моделювання властивостей такої сировини шляхом введення до їі складу БЖЕ, що стабілізують структуру i доповнюють дію м'ясних білків ( Shilman, 2003; Feiner, 2010).

Актуальність теми. Вирішення питань, пов'язаних зі створенням науково-обгрунтованих підходів до удосконалення існуючих технологій шинкових виробів в оболонці з використанням білко- 
во-жирових емульсій з метою моделювання їх складу, в т. ч. відповідно до існуючих медико-біологічних вимог, є доцільним і актуальним.

Варто зазначити, що вміст насичених, мононенасичених і поліненасичених жирних кислот істотно розрізняється в окремих видах сировини тваринного походження, внаслідок чого достатньо складно досягти необхідного рівня їхньої концентрації та співвідношення в готовому продукті. Користь свинячого жиру полягає в тому, що він містить особливо важливі для організму людини вітаміни, зокрема провітамін А, лінолеву кислоту та набагато більшу кількість незамінних жирних кислот, ніж у значній частині інших твердих жирів, а також характеризується невисоким вмістом холестерину (Kudryashov et al., 2002).

Жир індиків - відмінний продукт. Він легко засвоюється, плавиться при низькій температурі, має приємний запах та смак. Порівняно з іншими видами жирів тварин, індичий продукт містить рекордну кількість вітамінів групи Е, а також D.

Враховуючи, що поліненасичені жирні кислоти належать до есенціальних факторів харчування, їхній мінімальний вміст у добовому раціоні повинен становити від 2 до 6 г, при цьому дуже важливо, щоб співвідношення $\omega-6: \omega-3$ (оцінюване, як правило, за кількістю лінолевої і ліноленової кислот) відповідало від 8:1 до 10:1. У структурі сучасного харчування громадян України реальне співвідношення $\omega-6: \omega-3$ становить від 20:1 до 30:1, тобто існує дефіцит $\omega-3$ жирних кислот (Rogov, 2007).

Тому мета роботи полягала у створенні реструктурованих шинкових виробів підвищеної харчової та біологічної цінності шляхом збагачення їх амінокислотного та жирнокислотного складу.

Згідно з поставленою метою були визначені основні завдання: проаналізувати фізичні та хімічні властивості та вивчити жирнокислотний склад свинячого та індичого жиру, розробити БЖЕ зі збалансованим жирно-кислотним складом та розробити реструктурований шинковий виріб підвищеної харчової та біоло- гічної цінності 3 індичого м'яса та м'яса свинини 3 використанням БЖЕ та додаткових джерел тваринного білка.

\section{Матеріали і методи досліджень}

При визначенні органолептичних, фізико-хімічних показників тваринних жирів та їх сумішей, хімічного складу емульсії та готових продуктів використовували стандартні методи досліджень. Амінокислотний склад білків визначали методом іонообмінної хроматографії на колонках з використанням автоматичного аналізатора амінокислот Т-339 М. Жирнокислотний склад визначали згідно з ДСТУ ISO 5509-2002 «Жири та олії тваринні і рослинні». Визначення жирних кислот здійснювали на газовому хроматографі виробництва Hewlett-Packard HP6890 із полум'яно-іонізаційним детектором, інжектор S/S з виділенням потоків, колонка $\mathrm{Sp} 2380$, довжина 100 м, внутрішній діаметр 0,25 мм, товщина покриття 0,2 мкм.

\section{Результати та їх обговорення}

Оптимізацію співвідношення індичого та свинячого жирів у складі жирової суміші здійснювали шляхом математичного моделювання. Методом розрахунків прийшли до оптимального співвідношення свинячого - 40\% та індичого жиру - 60\%. Дослідження жирнокислотного складу ліпідів та оцінка їх збалансованості (табл. 1) показали, що переважаючими жирними кислотами в суміші $є$ з насичених жирних кислот - пальмітинова і стеаринова, з мононенасичених олеїнова, а $з$ поліненасичених - лінолева. Проте цінність жирового компоненту характеризується не тільки абсолютним вмістом окремих кислот, а й їхнім співвідношенням. Так, співвідношення суми ненасичених і насичених кислот в ліпідах суміші свинячого і індичого жирів становить 66,42:28,99 проти рекомендованого $70: 30$.

Жирнокислотний склад тваринних жирів та їх суміші

\begin{tabular}{|l|c|c|c|}
\hline \multicolumn{1}{|c|}{ Жирні кислоти } & $\begin{array}{l}\text { Масова частка жирних кислот } \\
\text { (г) у 100 г свинячого жиру }\end{array}$ & $\begin{array}{l}\text { Масова частка жирних кислот } \\
\text { (г) у 100 г індичого жиру }\end{array}$ & $\begin{array}{l}\text { Масова частка жирних } \\
\text { кислот (г) у 100 г суміші }\end{array}$ \\
\hline Міристинова $\left(\mathrm{C}_{14: 0}\right)$ & 1,4 & 0,64 & 23,37 \\
\hline Пальмітинова $\left(\mathrm{C}_{16: 0}\right)$ & 24,3 & 1,27 & 5,07 \\
\hline Стеаринова $\left(\mathrm{C}_{18: 0}\right)$ & 12,5 & 0,41 & 43,68 \\
\hline Олеїнова $\left(\mathrm{C}_{18: 1}\right)$ & 43,19 & 43,17 & 21,57 \\
\hline Лінолева $\left(\mathrm{C}_{18: 2}\right)$ & 19,4 & 22,27 & 0,94 \\
\hline Ліноленова $\left(\mathrm{C}_{18: 3}\right)$ & 0,7 & 1,51 & 0,12 \\
\hline Арахідонова $\left(\mathrm{C}_{20: 4}\right)$ & 0,21 & 0,11 & \\
\hline
\end{tabular}

Модельні зразки БЖЕ були відпрацьовані з використанням молочного білка - казеїнату натрію «DairiCo», білка глобіну крові «Vepro $95 \mathrm{HV}$ та індичої шкурки. Казеїнат натрію та глобін крові - тваринні білки, що володіють високими функціонально-технологічними властивостями, зокрема емульгуючою i жирозв'язуючою здатністю. Вони є активними емульгаторами і здатні адсорбуватися на поверхні часток жиру і утворювати міцний адсорбційний шар, запобігаючи ймовірним утворенням жирових напливів.
Розробку раціонального складу емульсії здійснювали методом комп'ютерної оптимізації на основі хімічного складу інгредієнтів, що рекомендуються до складу БЖЕ. Як функцію цілі було обрано жироутримуючу здатність, яка є критерієм стабільності утримання жиру в м'ясних емульсіях. Результати розрахунку композиційного складу білково-жирової емульсії подано в табл. 2. Хімічний склад БЖЕ подано в таблиці 3. 
Рецептура білково-жирової емульсії

\begin{tabular}{|l|c|c|}
\hline \multirow{2}{*}{ Найменування компонентів } & \multicolumn{2}{|c|}{ Вміст складових БЖЕ, \% } \\
\cline { 2 - 3 } & БЖЕ 1 (контроль) & БЖЕ 2 \\
\hline Жир свинячий & 43 & - \\
\hline Жирова суміш (жир свинячий 40\% + жир індичий 60\%) & - & 44 \\
\hline Вода питна & 43 & - \\
\hline Шкурка свиняча варена & 14 & 2 \\
\hline Суміш білків (глобін крові Vepro 95 HV, казеїнат натрію) & & 10 \\
\hline Стабілізатор білковий із індичої шкурки & - & 100 \\
\hline Всього & 100 & \\
\hline
\end{tabular}

Хімічний склад білково-жирової емульсії

Таблиия 3

\begin{tabular}{|c|c|c|}
\hline \multirow{2}{*}{$\begin{array}{c}\text { Показники } \\
\text { (масова частка, \%) }\end{array}$} & \multicolumn{2}{|c|}{ Білково-жирова емульсія } \\
\hline & БЖЕ 1 (контроль) & БЖЕ 2 \\
\hline Вологи & $45,3 \pm 1$ & $47,1 \pm 1$ \\
\hline Білка & $5,4 \pm 0,1$ & $8,6 \pm 0,1$ \\
\hline Жиру & $43,3 \pm 1$ & $40,9 \pm 1$ \\
\hline $\begin{array}{l}\text { Співвідношення білок:жир } \\
\text { білок:волога } \\
\text { білок:жир:волога }\end{array}$ & $\begin{array}{c}1: 8 \\
1: 8,3 \\
1: 8: 8,3\end{array}$ & $\begin{array}{c}1: 4,7 \\
1: 5,5 \\
1: 4,7: 5,5\end{array}$ \\
\hline
\end{tabular}

Дані таблиці показують, що критерії оптимальності, встановлені в задачі, повністю виконані, оскільки співвідношення білок:жир:волога в розробленій рецептурі БЖЕ відповідає рекомендованому діапазону 1:(3-5,7): $(3: 5,7)$.

Результатами досліджень доведено, що рівень функціонально-технологічних властивостей емульсій перебуває в прямій залежності від співвідношення компонентів, таких як казеїнат натрію, білок глобіну крові та кількості жировмісної сировини. Білок казеїнат натрію та білок глобіну крові мають вищу емульгуючу здатність порівняно 3 колагеновим білковим стабілізатором зі свинячої шкурки, що пояснюється різними походженнями білків. Встановлено, що найкращі вологозв'язуючі і емульгуючі властивості композиції білків казеїнату натрію та Vepro 95 HV харак- терні для співвідношенні 1:1, виявляються при рівні емульгування та гідратації 1:23-24. Отримане композиційне співвідношення БЖЕ здатне забезпечити іiі стабільність на рівні 97,8-98,9\%.

3 метою обгрунтування варіаційного комбінування м'ясної і жирової складових шинки було розраховано iii раціональний склад: $40 \%$ індичого м'яса, $40 \%$ свинячого та 20\% білково-жирової емульсії. Розрахована рецептура шинкового виробу дозволила підвищити його біологічну цінність за вмістом незамінних амінокислот порівняно з контрольним зразком на $9,6 \%$. В таблиці 4 наведено амінокислотний склад реструктурованої шинки зі збалансованим амінокислотним складом та збагаченої ненасиченими жирними кислотами.

Табличя 4

Амінокислотний склад шинкових виробів в оболонці, продукту

\begin{tabular}{|l|c|c|c|}
\hline \multirow{2}{*}{ Назва амінокислот } & \multicolumn{2}{|c|}{$\begin{array}{c}\text { Контроль: шинка «До сніданку» } \\
\text { ДСТУ 4668:2006 }\end{array}$} & $\begin{array}{l}\text { Еталон } \\
\text { (білок } \\
\text { яйця), г/100г }\end{array}$ \\
\cline { 2 - 3 } & \multicolumn{2}{|c|}{ Вміст амінокислот, г/100 г білка: } & 36 \\
\hline \multicolumn{1}{|c|}{ Незамінні: } & $40,59 \pm 1,81$ & $44,50 \pm 1,92$ & 5,00 \\
\hline Валін & $5,15 \pm 0,15$ & $5,74 \pm 0,14$ & 4,00 \\
\hline Ізолейцин & $4,29 \pm 0,21$ & $4,84 \pm 0,32$ & 7,00 \\
\hline Лейцин & $7,65 \pm 0,32$ & $7,99 \pm 0,30$ & 3,50 \\
\hline Лізин & $7,73 \pm 0,31$ & $8,64 \pm 0,52$ & 4,00 \\
\hline Метіонін+ цистин & $3,63 \pm 0,15$ & $3,84 \pm 0,12$ & 1,00 \\
\hline Треонін & $4,25 \pm 0,20$ & $4,57 \pm 0,22$ & 6,00 \\
\hline Триптофан & $1,16 \pm 0,05$ & $1,31 \pm 0,05$ & \\
\hline Фенілаланін + тирозин & $6,73 \pm 0,24$ & $7,57 \pm 0,37$ & \\
\hline Замінні: & & & $0,88 \pm 0,41$ \\
\hline Оксіпролін & $1,23 \pm 0,06$ & 0,89 & \\
\hline Коефіціснт утилітарності & 0,75 & & \\
\hline
\end{tabular}

Дані таблиці 4 свідчать, що дослідний і контрольний зразки шинки не містять лімітуючі амінокислоти. Коефіцієнт утилітарності «U» наближається до одиниці, що свідчить про високу біологічну цінність продуктів як за вмістом незамінних амінокислот, так і за вмістом оксіпроліну та коефіцієнтом утилітарності білка.

Загальна органолептична оцінка дослідного зразка реструктурованої шинки є високою. Так, смак та аромат дослідних зразків є кращими за контрольний зразок, який є більш сухим та жорстким за консистенці- 
єю. Саме введення БЖЕ дозволило поліпшити консистенцію готового продукту, підвищити його соковитість і загалом підвищити його органолептичні якості.

\section{Висновки}

1. Оптимізовано співвідношення індичого та свинячого жирів як 60:40 у складі БЖЕ та розраховано іiі жирнокислотний склад: співвідношення суми ненасичених і насичених кислот в ліпідах суміші свинячого та індичого жирів становить 66,42 : 28,99 проти рекомендованого $70: 30$.

2. Дослідження хімічного складу білково-жирової емульсії показало, що співвідношення білок:жир:волога в розробленій рецептурі БЖЕ відповідає рекомендованому діапазону $1:(3-5,7):(3: 5,7)$.

3. Було вивчено та розраховано амінокислотний склад обраної м'ясної сировини у співвідношенні 40\% індичого м'яса та $40 \%$ свинячого, що дозволило поліпшити біологічну цінність шинкового виробу за вмістом незамінних амінокислот на 9,6\% порівняно 3 контрольним зразком.

Перспективи подальших досліджень. Проведені дослідження дозволяють стверджувати, що удосконалення технології реструктурованих шинкових виробів на основі комбінаційного варіювання їх складу є перспективним і потребує подальшого удосконалення 3 метою отримання виробів підвищеної харчової та біологічної цінності для різних вікових груп населення.

\section{Бібліографічні посилання}

Artemova, E., Ivannikova, T. (2002). Teoreticheskie osnovy tehnologii productov pitaniya. M.: KolosS (in Russian).

Zonin, V.H. (2005). Sovremennoe proizvodstvo kolbasnuh I soleno-kopchenuh izdeliy. SPb.: Professiya (in Russian).

Kudryashov, L.S. Semenova, A.A., Kupriyanov, V.A. (2002). Perspektivy sozdaniya funktsionalnuh produktov pitaniya na myasnoy osnove. Vse o myase. 3, 13-17 (in Russian).

Rogov, I.A. (2007). Himiya pischi. Kn.1 (Belki: struktura, funktsii, rol v pitanii. M.KolosS (in Russian).

Salavatulina, R.M. (2005). Ratsionalnoe ispolzovanie syrya v kolbasnom proizvodstve. SPb.: ZAO Torgoviy dom Geord (in Russian).

Feiner, G. (2010). Myasnyye producty. Nauchnye osnovy, tehnologii, prakticheskie recomendatsii. $\mathrm{SPb}$.: Professiya (in Russian).

Shilman, L.Z. (2003). Fiziko-himicheskiye izmeneniya zhyrov pry ispolzovanii ih v obschestvennom pitanii. Saratov: SGTU (in Russian).

Clark, D.C., Alan, R.M., Pete, J. (1994). Differences in the structure and dynamics of the adsorbed layers in protein stabilized model foams and emulsion. Royal Society of Chemistry. Faraday Discussion. 98, 253-262.

Стаття надійшла до редакції 10.03.2017 